\title{
Notice of a Few More Early Christian Gems
}

By C. Drury E. Fortnum F.S.A., etc.

To cite this article: By C. Drury E. Fortnum F.S.A., etc. (1885) Notice of a Few More Early Christian Gems, Archaeological Journal, 42:1, 159-170, DOI: 10.1080/00665983.1885.10852173

To link to this article: http://dx.doi.org/10.1080/00665983.1885.10852173

曲 Published online: 15 Jul 2014.

Submit your article to this journal

Q View related articles $₫$ 


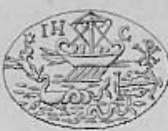

1

(a)
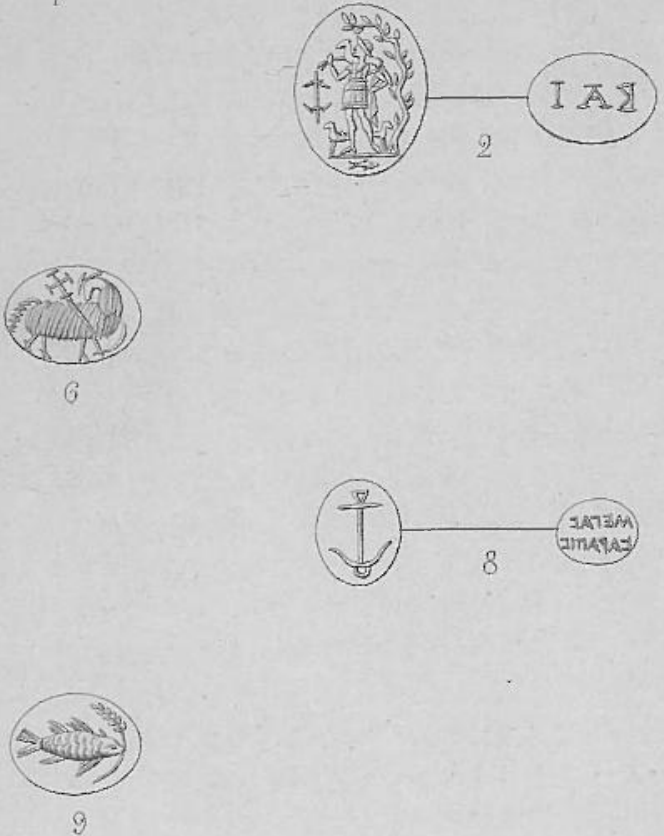

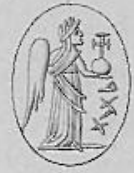

5
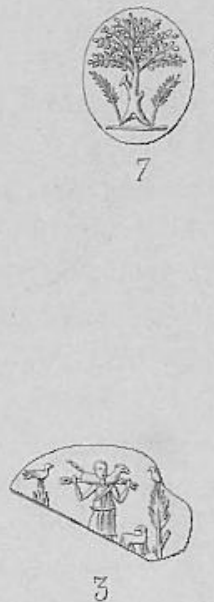

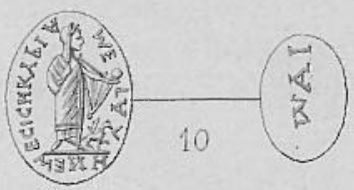




\section{NOTICE OF A FEW MORE EARLY CHRISTIAN GEMIS,}

By C. DRURY E. FORTNUM, F.S.A., etc.'

On some former occasions I have had much pleasure in directing the attention of members of the Royal Archæological Institute to various rings and engraved gems in my own and other collections, the workmanship of the arlier centuries of our era, whereon are represented in itaglio upon the metal, or upon the stones encased ierein, emblems or subjects having indirect or symbolic eference to Christianity. The descriptive remarks read $\checkmark$ the Institute on those occasions were honoured by publication in the Archcoological Journal, and may be found by reference to vols. xxvi, p. 137 ; xxviii, p. 266 ; xxix, 305 ; xxxiii, p. 111, and lastly in vol. xxxvii at page 351 .

Since the last publication I have been fortunate enough to acquire some other. early christian gems of not less interest than those considered in my former papers, some description and remarks on which, together with an illustrative engraved plate, I would now offer to the Society.

For the convenience of those who take interest in this special branch of antiquarian enquiry I would propose to number the objects now to be described in sequence of those which were the subjects of my. former papers, the last gem in which was numbered 13.

Of those now under consideration No. 1 on the illustrative engraved plate, on which they are figured of the actual size, will be No. 14 of the collective and descriptive list, and so forward.

These gems are from various sources, some kindly ceded to me by my friend the Rev. Greville Chester, others from the collection of Dr. Dressel, some from my own gather-

\footnotetext{
1 Read at the Monthly Meeting of the Institute, May 7,1885 , when the objects
} 
ing; and independently of my own belief in their integrity, all have been submitted to the careful scrutiny of no less than five or six of the best judges of my acquaintance, who were agreed in considering them genuine and antique.

No. 14. A nicolo of oval form, which from certain fine crackling on the surface would seem to have been subjected to the action of fire, but insufficient to do more than sligbtly impair the purity of the white stratum. (See plate fig. 1.) Its surface is covered with subject in intaglio. Above is the ship, emblematic of the voyage of life and, perhaps subsequently, of the church, and in the field over it are the letters I H C.' De Rossi, Garrucci, and the late much regretted Padre Broussa consider that the ship with these initials of Christ above it, is typical of Him and of His church. To the right (in the impression and as seen in the engraving) is the chrisma, beneath which an anchor with a fish on either side, the head of the upper one being towards the top, that of the lower fish towards the flukes of the anchor, viz., counter-naiant as in the sign Pisces.

On the other side, the left, Jonas, with a star above him, is being ejected by the marine monster ${ }^{2}$ whose serpentine body and fish-like tail extend across the field, here spotted over with oblong cuts from the scalptor's wheel to indicate the water of the great deep, in which and below a dolphin swims.

I have before suggested and, then unknown to me, a similar idea has been advanced by the late Canon Martigny, that the two fish with the anchor may have connubial reference, and supposing this to be the fact, may we not venture to interpret this complex representation of Christian emblems as follows : viz., that the stone was originally set in a marriage ring-that the fish, the wedded pair, united in hope (the anchor) under Christ (the chrisma) that the voyage of life (the ship) or the church of Christ of which they are disciples, may lead them to the resurrection (Jonah) to Eternal life? (the star). This may be a too poetical surmize, but it would at least give some

\footnotetext{
${ }^{2}$ As on a gem of the Borgia coll. and elsewhere.

2 The "whale" "represented with Jonah
}

is the "pristis" (Pliny His. Nat. xxiv, 19, 8), pristas or pristes, i.e., Sea monsters. 
reason for the occurrence of so many emblems together, and in the relative positions in which they are seen on this curious gem.

Or, on the other hand, it may be suggested that the two fish are hopefully united under the sacred monogram as members of the Church of Christ (the ship) and so on.

It may also be argued that although those gems on which two fish are represented, one on each side of the stem of cross or anchor, the heads of which are in the same direction, may have matrimonial reference, ${ }^{1}$ the fact that the fishes on this gem are placed head to tail, as in the Zodaical sign, would be against such an inference.

It came from Beirut in Syria and is of fairly good workmanship. In the opinion of some of the more learned Roman antiquaries it is of classic time, probably of the later years of the third century, and may be even anterior to Constantine, the chrisma having been known previous to its adoption by him for the Labarum.

No. 15 (fig. 2). The gem engraved under this number is also one of considerable interest. On the face of an oval piece of red jasper we have the following representation in intaglio. A figure, undoubtedly representing the Good Shepherd, stands erect, his weight borne upon the right leg and foot, the left being slightly bent backwards, the toe touching the ground. He is clad in the usual short tunic, \&c., a pallium or shawl falling from the left shoulder is held by that hand. On and over his right shoulder and back he holds the sheep or lamb, its fore legs being held by his raised and extended right hand. He looks upwards to his right and the usual domed shepherd's hat is on the head. ${ }^{2}$ On either side a sheep is standing on the ground from which a tree of serpentine growth, doubtless intended for a vine, rises spreading above his head; below his feet and the incised line indicating the ground on which he stands, a fish is swimming, while on the field of the gem immediately before him is an anchor. Here then again we have several well known emblems combined on the same gem. In section, this jasper is an oval thin truncated cone, the base

\footnotetext{
1 The laying together the extended index fingers of each hand is a well known sign referring to marriage in the East.
}

\footnotetext{
2 These descriptions of attitude are as seen in the impressions from the intaglio on which they are reversed.
} 
of which is the face of the gem, the reverse being an oval of smaller surface, and on this we find incised the letter's, as shown in the engraving, IA\&. My first impression on examining this intaglio (which was kindly secured for me by my friend Dr. Dressel, whose practised eye is authoritative as to the genuineness of an antique) was that these letters were to be read as the well known IA $\omega(\Omega)$ the third letter being accidentally and wrongly written on its side. On showing the gem to my friend the learned Padre Garrucci he doubted that such a form of the letter could have been unintentional. Further consideration of the subject and reference to notes, \&c., led to the conclusion that the letter in question was a B (beta) not a $\omega$ wrongly inscribed, and that the word was to be read the other way, as on the stone, BAI, being an abbreviation of Basoy. On referring to Sueceri (J.C.) Thesaurus Ecclesiasticus, Vol. i., sub. voc. Bary it is explained as of Egyptian origin and signifying "ramus palmo" a palm branch. Sueceri refers to

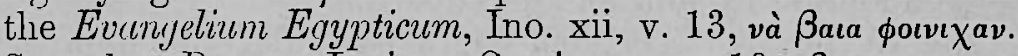
See also Peyron Lexicon Copticum, p. 19, $\beta$ aıy, ramas palmce, the emblem of Martyrdom and of Victory. BAI would also signify the soul (King) and also a prize $=$ the palm branch. The workmanship of this gem is good and its preservation perfect; it is probably of the first half of the third century, according to the opinion of the Com : De Rossi, who thought the inscription, reading it as IA $\omega$ indicated a Gnostic tendency on the part of the original owner.

No. 16 (see plate 3) is a gem, a carnelian or sard much broken, which was referred to in my former paper (page 359) as then belonging to Dr. Dressel, but since acquired by me; on which we have the Good Shepherd standing between, probably, two sheep but one only remains, beyond on either side is a cypress tree on each of which a bird is perched. Here we have the sheep, the disciples or church on earth, and the birds their spiritual state in heaven, perhaps also typifying the Jewish and Christian churches mundane and celestial-a curious and interesting figurative representation, well executed. It also is a work probably of a somewhat later period of the third century.

No. 17. At the dispersion of the Castellani collection in 
Rome last year, I acquired another gem of similar character to that figured on page 359 of my last paper (No. 2). It is a nicolo of fairly good workmanship, probably of the advanced third century; the Good Shepherd carrying the lamb or sheep seems to be advancing towards his right, beneath the spreading branch of what is probably intended for a vine, a sheep is on either side, the whole group reversed in arrangement, but much resembling that on the red jasper (No. 2 on the plate), but beyond the sheep on the ground before him is what appears to represent a bird, above which is an object like the letter $J$, as seen on the intaglio, but longer in proportion to its width, and which may be intended for a shepherd's crook or pedum, if not a letter, in which case it would probably be the initial of the original owner of the gem. I believe, however, that it represents the shepherd's crook, as, on sealing, the letter would be reversed.

A similar subject on a nicolo, but varied from that just described, was also sold at the Castellani sale; it was in bad condition, chipped and of coarse inferior workmanship.

In the Ravenna Library are two gems, a crystal and a carnelian, on each of which is a pastor bonus in intaglio of very rude execution.

By way of illustration I have laid on the table a terracotta lamp, on which the subject of the Good Shepherd is seen in relief surrounded by bunches of grapes.

I would also direct attention to the interesting and perfectly preserved archaic Greek bronze statuette representing the Hermes Criophoros, a nude figure, his head only covered by a close fitting cap or hood and carrying a ram sheep on his shoulders. This little group, found in the neighbourhood of Santa Maria Capua, is referred to by the late $\mathrm{M}$. Veyries ${ }^{1}$ in his interesting monograph on Criophoric figures of Greek, Roman and early Christian times, and is probably of a date considerably anterior to the third century B.C.

In it we have the type adopted in later time by the early Christians in representing the Good Shepherd as we

1 Teyries, M.A., Les Figures Criopha-

Ecoles Fr. d'Athenès et de Rome.

es. Paris, 1884, p. 7, No. 11. Bib. des 
see it upon the lamp, and upon the engraved gems I have just described.

This "Hermes" carrying the young male sheep or goat may merely represent a peasant bringing an offering to the shrine of his favourite deity, and in this respect such group may have been considered as doubly typical by the Christian mind, the young male sheep, of the first of the flock, representing that Lamb, without spot, who was offered for us all; while, on the other hand, as a shepherd carefully bearing the young or weakly ram, would signify the disciple gently borne on the loving neck of Him who is the Shepherd of our souls. The group would thus have two-fold significance, although there can be little doubt that it was in the latter sense as the pastor bonus that it was generally accepted and represented.

The gem described under No. 10 in my last paper (No. 4 in our plate) is a nicolo, the intaglio on which is of similar character to a stone referred to by Martigny and to one by Gorli; on the gem figured by the latter, the fish hang from the arms of a cross, which in no way resembles an anchor. On that now under notice the anchor is reversed in position, the fish hanging by their heads one on each side of the stem. The work is coarsely executed but somewhat deeply cut, and probably of the later years of the third or early fourth century; found in Egypt.

The two fish-if such representation has no connubial reference-are believed by some to typify the multiplication of the food-Christ's body; the anchor-the cross; or, the faithful attracted or attached to an eucharistic or other emblem of the faith (vide De Rossi, Bul. 1879, p. 109) two fish, with emblem, the two conjugi united, yoked, or mated together under the faith- " pisciculi secundum Iesum Christum" to quote Tertullian.

In the library at Ravenna are two Christian gems, on one, a green jasper, is an anchor between two fish; on the other, a carnelian, a cross between two fish.

No. 18 (No. 5 on the plate) is a gem of similar material and character to that described in my former paper under No. 12. It is an intaglio on pyrites, and represents a winged draped figure, an angel or victory holding an orb surmounted by a cross potent, (the crux ansata reversed,) and an inscription below, which Mr. King rather agreed 
with me in reading pax from an impression, but which may be of badly formed Greek letters X XT, and the initials of the owner. It came from Egypt and is rudely executed, but somewhat in the early Byzantine manner of the fifth and early sixth century; its oriental origin would be strong reason for the inscription being in Greek, rather than in Roman letters. On the gem (No. 12) described in my last paper, the victory holds a double cross, an emblem which, it would seem, does not appear till the period' of Justinian II. The victory with orb and cross on that now under consideration, occurs on coins of Arcadius after 383 A.D. The double cross, i.e., the cross having above the lateral arms a smaller cross-bar, may probably have taken its origin from the title affixed over the head and bearing the well known superscription which Pilate would not alter.

The intaglio now under notice is larger than that No. 12, and better in execution, though very coarse, as might be expected on so harsh and ungrateful a material.

No. 7 on the engraving (numbered 19 in my list) figures an intaglio upon sard found at Rome, the Christian significance of the subject on which, a spreading tree between two branches of palm, was open to some doubt; my own opinion was that it was intended to represent the tree of life. That opinion is in a measure confirmed by the representation of a similar tree upon the side of one of those Egyptian earthern flasks which are (when hollow) supposed to have contained oil from the shrine of St. Menas, or were tokens of that Saint, and which generally bear his figure with arms extended between two camels, with an inscription surrounding or on the other side.' That bottle, the Christianity of which is manifest, was brought over by the Revd. Greville Chester and is now in the British Museum; it has not the figure of the saint, but the usual inscription

\section{(Tov a \\ TIOVM}

HNA

is on one side: and the tree on the other.

Another instance of the tree occurs in intaglio on a small plasma gem, which I subsequently procured in

${ }^{1}$ An example was exhibited.

VOI, XLII, 
Rome; on it is a wide spreading tree having on either side an ear of corn.

It seems to me that, however we may differ on the precise significance of these representations, there can be little doubt that they are of Christian symbolism and that the principal figure is intended for the tree of life. In the one case the palm may refer to victory over sin and death unto eternal life-the tree-which can hardly be intended for a vine, or the explanation would be manifest. The ears of corn on the smaller stone must have reference to the bread, the typical of body of the Lord.

The tree occurs on gems together with the Good Shepherd, as on some we have described, but it is of different form and character of growth, (see also Bull. Arch. Ch. 1879, T. vii) and painted in the catacombs (Bull. 1876, T. ix). The persea tree or Sebestene plum (Cordia Myxa), wreathes of whose branches were ordered by Alexander to be used as prizes in the games he instituted at Alexandria, and the leaves of which frequently adorn the head of Horus, could hardly be that figured upon the S. Menas bottle, nor upon the two gems under consideration. If not the tree of life, as I believe, it might rather be intended for that tree at Matareyeh by Heliopolis under which the Holy Family are said to have reposed on their flight into Egypt, but if so the reference is Christian.

No. 8 on the engraving (No. 20 of our list) is a stone which would seem to be a mottled brown jasper, on one face of which an anchor is incised of the form usually found on Christian gems, and probably intended as a Christian emblem ; on the reverse however is the inscription honouring Serapis METAC CAPAחIC, a curious record of the intermingling of the two Cults, Serapis being honoured as a type of Christ. Merivale (History of Rome) states that Serapis and Christ were, in the time of Hadrian, equally worshipped as being nearly identical. Mr. King (Gnostics, p. 68) refers to "the curious letter of Hadrian to Servianus" from which he quotes "Those who morship "Serapis are also Christians; even those who style them"selves the bishops of Christ are devoted to Serapis. The "very patriarch himself when he comes to Egypt is forced "by some to adore Serapis, by others to adore Christ. 
"There is but one God for them all, him do the Christians, "him do the Jews, him do all the Gentiles also worship."

Noble sentiments worthy of that enlightened Emperor.

The execution of this inscription is sharp and clean, and the work may be of the later second or earlier third century. The gem was found in Egypt.

Figure No. 6 (21 of our list) is a very pale oval amethyst, on the slightly convex face of which is incised what is doubtless intended to represent a lamb holding a cross-an Agnus Dei. It is interesting as an early representation of the subject on a gem, being probably of the fifth or sixth century, and for the very rude manner in which the intaglio is executed, probably by some local artist. As seen in the impression the lamb is walking to the right; the head surmounted by the nimbus being turned over the back; the cross is of the form known as potent, an elongated stem being attached to the lower limb.

No. 9 on the engraved plate, No. 22 of my list, represents a gem of the genuineness of which I could hardly feel quite assured, but on submitting it to the careful examination of three of the best judges of antique gems at Rome, all were satisfied of its antiquity. It is an amethyst of oval form, on the slightly convex face of which is incised the figure of a fish, swimming, and holding in its mouth what seems to be intended for a spray of olive rather than an ear of corn or a palm, as it will be noticed that the leaves alternate and are not one opposite the other. A curious representation which I do not recollect to have seen recorded, but can hardly have other than Christian significance. Could it be intended to convey that the fish-the Christ-brings peace and happiness to the believer- "peace be unto you," "my peace I give to you"? $\mathrm{Or}$ is it the disciple who has received and holds that emblem of his peace in Christ?

The work of the intaglio is fairly good, and may be of the third or early fourth century. It was procured at Rome.

In my last paper (Arch. Journal, vol. xxxvii, p. 362) on Christian rings and gems I figured and clescribed under No. 11 a circular intaglio on garnet, on which is incised an erect draped figure with laterally outstretched arms, 
beneath each of which is an animal, I believe to be intended for a lion, with head down as crouching beneath the central figure. This I concluded was no other than a representation of Daniel in the lion's den; but some learned antiquaries have thought that $\mathrm{S}$. Menas and his camels, rather than Daniel and the lions, was the subject of the intaglio. On showing the gem to the Padre Garrucci he quite agreed with my view, and considers the representation of importance as typical of Christ; the attitude denoting the crucifixion and the scared lions His persecutors the Jews. See also De Rossi, Bull. Inst., 1872, 1,av. II., who agrees in my opinion, as to the subject being Daniel and not S. Menas.

For other representations of Daniel on gems see Garrucci, (Storia, plates 478 and 492), one of these is in a reliquary at the Duomo in Cividale; the other at Vienna.

Mr. King (Gnostics, p. 142) refers to a sard gem formerly in the Hertz collection having the Good Shepherd between two tigers (or lions?) looking up at him with the legend ESIVKEV which he writes "evidently cloaked the, at the time no doubt, dangerous confession KE (for K $\nu_{\rho} \iota \varepsilon$ ) IESV 'Lord Jesu help.'

This representation bears a curious analogy to that upon our garnet, and would seem to confirm the opinion that the Daniel on my gem was typical of Christ, who is figured as the Good Shepherd on the Hertz sard.

No. 10 on the engraved plate represents an interesting Gnostic gem, a green jasper with some red spots (bloodstone) the intaglio, of fair workmanship, and the inscription on which, I have Mr. King's authority for stating, are important ; being " an unpublished legend of much interest identifying Isis with the Moon, as Osiris was with the Sun, according to Plutarch. In this case, therefore, the adjunct IA $\omega$ is very appropriate that being, properly in the Greek form IAO $\Sigma$, merely a title of the autumnal "Sun."

On the face of the gem is incised an erect figure of Isis wrapped in the peplum, in the act of advancing to the right (in the impression) and holding the "cup of libation," in Mr. King's opinion, but which looks equally, from the indefinite workmanship of the intaglio, like a globular fruit, while along and up the arm is a straight line indicating portion of some instrument, but which two objects 
taken together may, not improbably, represent the simpulum or, more correctly, the cyathus by which libations were offered to the Gods. Before and at her feet is a gryphon, apparently holding some object beneath its right fore foot, (this I regret to see is not correctly rendered on the copper-plate). Beneath and around is the inscription already referred to, and which Mr. King, the first authority on Gnostic lore, reads-

ECICHKYPIA MEГAА HNEM, and translates 'Isis the mighty Lady of the moon.' In section the gem is a much truncated oval cone, on the reverse and smaller face is incised the IA $\omega$. I purchased this stone at Naples, but have reason to think that it may have been brought from Sicily.

I have ventured to publish this intaglio with the others, although it is not to be numbered among the Christian gems which are the special subject of the present paper, but I have done so firstly by reason of the interesting nature of its inscription, as pointed out by Mr. King, and secondly because there was an unoccupied space at the bottom of the engraved plate which I thought it would not too unworthily occupy.

I may here refer to some interesting notices of "Christian Gem-Types" by Mr. King and by Mr. S. S. Lewis, published in the "Communications" of the Cambridge Antiquarian Society, accompanied as they are by much learned comment and valuable reference. There also are described some Gnostic stones of curious interest.

I may also here record the following, which are preserved in the Museum at Parma, where I noticed nine coarsely executed early Christian gems, the subjects of which are :-

1. Carnelian-anchor, fish and IXBYE.

2. Yellow jasper-palm and wreath.

3. Carnelian-dove and palm incised on the reverse of an older pagan gem, the subject of which is nearly ground down.

4. Red jasper-Pastor bonus and two sheep below.

5. Plasma-dove and palm.

6. Fish and some letters.

7. Wreath and palm.

8. Anchor. 
9. Dove and palm.

They are, for the most part, unimportant.

In the collection of objects which belonged to Carlo Morbio, and which were dispersed by auction at Munich in Sept. 1883, were some gems and finger rings of which, judging from the description in the catalogue, some were of early Christian character, others probably mediæval.

While occupied in revising proof of the foregoing, I have received from my friend the Rev. Greville J. Chester, the oval bezel of a bronze ring from which the apparently simple hoop has been broken away. On it, figured in intaglio, is a boat extending across the field, in which three figures are seated; the centre one, in full face, draped and nimbed is, doubtless, intended for Christ; one sits at the prow, the other at the stern, Simon, probably, and another disciple; while from the depth below three fishes are rising toward the boat. This may be intended to represent the miraculous draught of fishes; or, with equal probability-Christ being in the boat and not on the shore-His preaching from the ship to the assembled multitude (Mark iv, 1) here typified by the fishes. The workmanship is rude, probably of late fourth or early fifth century. It was found at Smyrna. 